CZASOPISMO INŻYNIERII LACDOWEJ, ŚRODOWISKA I ARCHITEKTURY JOURNAL OF CIVIL ENGINEERING, ENVIRONMENT AND ARCHITECTURE

JCEEA, t. XXXII, z. 62 (3/I/15), lipiec-wrzesień 2015, s. 329-336

\author{
Dorota PAPCIAK ${ }^{1}$ \\ Justyna ZAMORSKA ${ }^{2}$ \\ Monika ZDEB $^{3}$
}

\title{
TREATMENT OF TECHNOLOGICAL WATER FOR THE AEROSPACE INDUSTRY - OPERATING PROBLEMS
}

\begin{abstract}
The paper presents the water treatment technology for FPI line (Fluorescent Penetrant Inspection) which is used to conduct diagnostic tests in the field of structural cracks, erosion, corrosion, defects of the material, welds cohesion. The problem that occurred during operation of the FPI line was an increase of turbidity and milky colour of water (i.e. white water) in bathtub of the last rinse which caused the formation of deposits on washed parts and hampered diagnostic process. On the basis of the physicochemical and bacteriological analysis the assessment of changes in water quality during the cleaning process was carried out. The problem of the formation of the so-called "white water" was described and solved. An analysis of necessity of water treatment station modernization as well as the legitimacy of the use of the disinfection process were made. The following parameters of water were analysed: $\mathrm{pH}$, turbidity, conductivity, hardness, dissolved oxygen, total organic carbon, permanganate index, $\mathrm{SiO}_{2}$ content, heavy metals contents, and the total number of mesophilic and psychrophilic bacteria. The results of the analyses indicate that the cause of the growth of technological water turbidity on the FPI, is formation of polysilicon acid. Polymerized forms of silicates exist in colloidal form, therefore, the observed phenomenon is the emergence of so-called "white water" and the formation of deposits.
\end{abstract}

Keywords: polymerized forms of silicates, water treatment, FPI - Fluorescent Penetrant Inspection

\footnotetext{
${ }^{1}$ Author for correspondence/ autor do korespondencji: Dorota Papciak, Rzeszow University of Technology, Al. Powstańców Warszawy 12, 35-959 Rzeszów, tel. 178651301, e-mail: dpapciak@ prz.edu.pl

2 Justyna Zamorska, Rzeszow University of Technology, Al. Powstańców Warszawy 12, 35-959 Rzeszów, tel. 178651301, jzamor@prz.edu.pl

3 Monika Zdeb, Rzeszów University of Technology, Al. Powstańców Warszawy 12, 35-959 Rzeszów, tel.178651301,mzdeb@prz.edu.pl
} 


\section{Introduction}

Fluorescence and Chemical Cleaning Line is used to diagnose parts that are subject to processes such as: wear and friction, corrosion processes and fatigue [6,7]. It allows for an assessment of structural components for cracks, erosion, corrosion, material losses, the consistency of the welds, etc. These studies are very important both at the stage of research prototypes and series production because they help identify and locate defects that can cause a crash $[4,6]$.

Detection of defects by using penetrants can be used by two methods: the first one is called a colourful method which involves applying a red penetrant liquid and developer of white colour. However, the second method is called fluorescent method, in which the penetrant liquid contains fluorescent additives. Observation of the test object by calling the liquid from the fissure, is carried out under UV light. Indications take the greenish-yellow colour. The location of defects in surface is fast and accurate [8].

The problem, which appeared during the operation of the line of the FPI, was an increase in turbidity and the emergence of the last milk rinsing water colour (called "white water"). At the same time, we have observed the formation of sludge washed items which made it difficult for the diagnostic process and forced the frequent exchanges of the water.

The purpose of the research was to identify the causes of the deterioration of the quality of the water of the last rinse in spite of the use of water purification process in closed circuit.

\section{Materials and methods}

Studies were carried out in three stages:

1. analysis of changes in water quality at each point of a water treatment technology for the FPI line (feed water tank, a gravel pack, ion-exchange resins, rinse water tank);

2. the cleaning and disinfection of final rinse closed circuit;

3. observations of changes in rinse water quality from the final washing stage at intervals of 2-9 days after the process of disinfection.

Physical and chemical analysis of the water was carried out based on the applicable test procedures in Poland (Tab. 1).

The following parameters of water were analysed: $\mathrm{pH}$, turbidity, conductivity, hardness, dissolved oxygen DO, total organic carbon TOC, permanganate index, $\mathrm{SiO}_{3}{ }^{2-}$ content, heavy metals contents, and the total number of mesophilic and psychrophilic bacteria. 
Table 1. Test methods

Tabela 1. Metody analityczne

\begin{tabular}{|l|l|}
\hline \multicolumn{1}{|c|}{ Parameter } & \multicolumn{1}{c|}{ Method } \\
\hline $\mathrm{pH}$ & potentiometric method Hach Lange \\
\hline Conductivity & potentiometric method Hach Lange \\
\hline Hardness & titration method \\
\hline Permanganate index & titration method \\
\hline Dissolved oxygen DO & potentiometric method Hach Lange \\
\hline Turbidity & spectrophotometric method Hach Lange \\
\hline $\mathrm{TOC}^{2-}$ content & SIEVERS InnoVOX TOC Analyser \\
\hline $\mathrm{SiO}_{3}{ }^{2}$ metals & spectrophotometric method with molybdic acid \\
\hline Heavy moth & X-ray spectrometer PICOFOX \\
\hline Psychrophilic and mesophilic bacteria & PN-EN ISO 6222:2004 \\
\hline
\end{tabular}

\section{Results and discussion}

Fluorescence and cleaning Line in the facility consists of four bathtubs. Rinsing the elements is produced by using the preparations which are driven by means of penetrants, developers, emulsifiers and removers (ZYGLO, TURCO and ARDROX).The last of the bathtubs, which is rinsing with clean water in a closed circuit is turned on, connected with the renewal of water. In circulation it includes: a water tank which adds water in the installation of the capacity of $1.8 \mathrm{~m}^{3} \mathrm{Z} 1$, two tanks for technological water $\mathrm{Z} 2, \mathrm{Z} 3$, two with a capacity of $10.5 \mathrm{~m}^{3}$ each, gravel filter $\mathrm{F}$, cation exchanger $\mathrm{Kt}$, anion exchanger An, bathtubs W1-W4. FPI line diagram is shown at the Fig. 1.

The problem of "milky water" was connected with technological water of the renewal of water. Initially, it has been suspected that the cause of the deterioration of its quality and the formation of sediments is a bad condition of the bacteriologic state. The suggestion that the reason for the increase in turbidity is proliferation like microorganisms stemmed from other water parameters, which pointed to the correct work of purification stations. All the parameters of physical and chemical with the exception of water turbidity were satisfactory (Tab. 2).

However, the number of bacteria in all samples of water were not large enough to be able to found the cause of the problem only in the bacteriological quality of (Tab. 3). In addition, the presence of a white precipitate showed pollution other than biological contamination. Taking into account the fact that since the launch, the line was not FPI cleaning, first recommended cleaning and disinfection of the closed circuit of sediment accumulated water. The disinfection process was conducted with peracetic acid and hydrogen peroxide STERINOX.

In preparation for this, there are two components of disinfectants for complementary action i.e. peracetic acid (15\%) and hydrogen peroxide (14\%). The first one is characterized by a short run time (half-life of 30-60 min) and 
a strong biocidal activity on all bacteria and gram-positive and gram-negative bacterial spores, viruses, fungi, algae, protozoa. It breaks down into harmless products: water, carbon dioxide, acetic acid and oxygen. In addition to the efficient operation of the disinfectant peracetic acid is characterized by a slight impact on properties of ion exchange resins [5,6]. The second component of the disinfectant hydrogen peroxide is acting less but much longer lasting and ensure maintenance of disinfected water for a period of a few days of not allowing recontamination of the water.

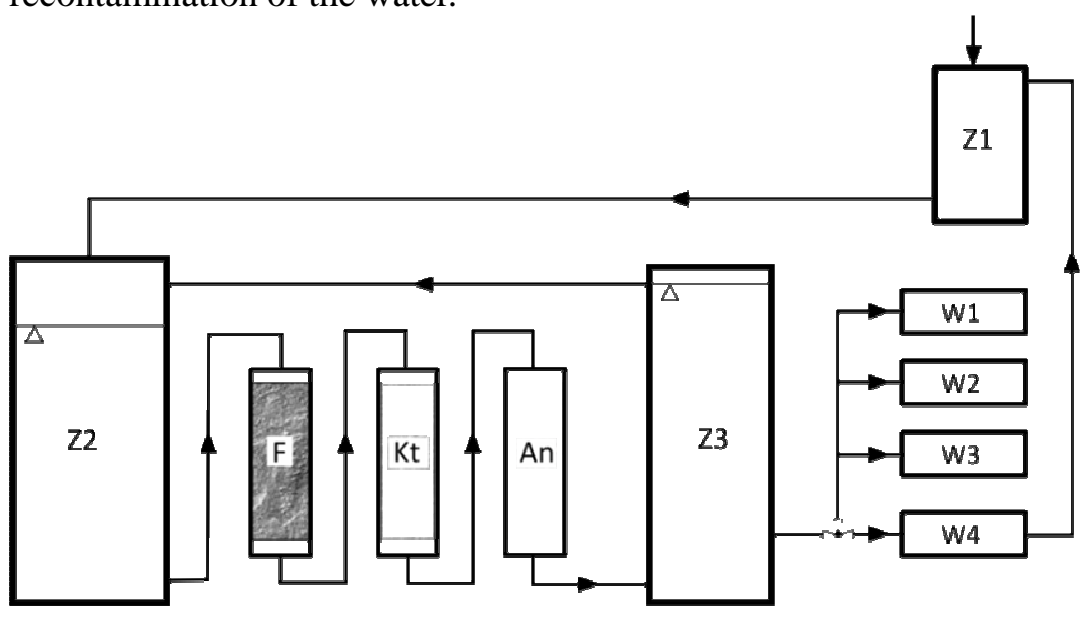

Fig. 1. Schematic diagram of FPI line

Rys.1. Schemat technologiczny linii FPI

Table 2. The quality of technological water on the FPI line

Tabela 2. Fizykochemiczne parametry wody technologicznej linii FPI

\begin{tabular}{|c|c|c|c|c|c|}
\hline Parameter & $\mathbf{Z 2}$ & $\mathbf{F}$ & $\mathbf{K t}$ & An & W4 \\
\hline $\mathrm{pH}$ & 7,53 & 6,21 & 3,79 & 4,53 & 5,62 \\
\hline Turbidity; NTU & 43,8 & 43,6 & 44,6 & 42,7 & 38,2 \\
\hline Conductivity; $\mu \mathrm{S} / \mathrm{cm}$ & 6,96 & 7,56 & 212,4 & 5,26 & 9,11 \\
\hline Total Hardness; mg $\mathrm{CaCO}_{3} / 1$ & 14 & 0 & 0 & 0 & 0 \\
\hline $\mathrm{DO} ; \mathrm{mg} \mathrm{O}_{2} / \mathrm{l}$ & 6,79 & 6,58 & 6,65 & 6,60 & 7,67 \\
\hline Permanganate index; $\mathrm{mg} \mathrm{O}_{2} / 1$ & 10,4 & 1,4 & 3,0 & 5,8 & 5,2 \\
\hline TOC; mg C/l & 1,51 & 0,99 & 0,57 & 0,22 & 0 \\
\hline $\mathrm{SiO}_{3}{ }^{2-} ; \mathrm{mg} \mathrm{SiO}_{2} / 1$ & 17,1 & 16,06 & 17.98 & 15,31 & 14,97 \\
\hline $\begin{array}{l}\text { Mesophilic bacteria; } \\
\text { CFU/1 ml }\end{array}$ & 50400 & 395000 & 86000 & 132500 & 680000 \\
\hline $\begin{array}{l}\text { Psychrophilic bacteria; } \\
\text { CFU/1 ml }\end{array}$ & 140000 & 112000 & 78000 & 18000 & 42000 \\
\hline
\end{tabular}


A small concentration of hydrogen peroxide will not cause excessive foaming during the preparation to carry out the process, which could result in a gaping of installation. Peracetic acid one of the most effective disinfectants is non-toxic to humans and is characterized by full biodegradability. Commercial preparation of this acid is a mixture of peracetic acid, acetic acid, hydrogen peroxide and water in accordance with the below described the reaction:

$$
\mathrm{CH}_{3} \mathrm{COOH}+\mathrm{H}_{2} \mathrm{O}_{2} \rightarrow \mathrm{CH}_{3} \mathrm{COOOH}+\mathrm{H}_{2} \mathrm{O}
$$

After dissolution and removal of accumulated sediments they are filled into system with clean water. The amount of bacteria in the water after disinfection process technology declined, but it still remained in large quantity (Tab. 3.).

Table 3. The parameters of the last rinse water W4

Tabela 3. Parametry wody w wannie z ostatniego płukania

\begin{tabular}{|c|c|c|}
\hline Parameter & Before disinfection & After disinfection \\
\hline $\mathrm{pH}$ & 5,62 & 8,68 \\
\hline Turbidity; NTU & 38,2 & 1,62 \\
\hline Conductivity; $\mu \mathrm{S} / \mathrm{cm}$ & 9,11 & 4,577 \\
\hline Total Hardness; $\mathrm{mg} \mathrm{CaCO}_{3} / \mathrm{l}$ & 0 & 0 \\
\hline $\mathrm{DO} ; \mathrm{mg} \mathrm{O}_{2} / \mathrm{l}$ & 7,67 & 8,44 \\
\hline Permanganate index $; \mathrm{mg} \mathrm{O}_{2} / 1$ & 5,2 & 1,3 \\
\hline TOC; mg C/l & not detected & not detected \\
\hline $\mathrm{SiO}_{3}{ }^{2-} ; \mathrm{mg} \mathrm{SiO}_{2} / \mathrm{l}$ & 14,97 & 21,50 \\
\hline Mesophilic bacteria ; CFU/1 ml & 680000 & 14500 \\
\hline Psychrophilic bacteria; CFU/1 ml & 42000 & 12900 \\
\hline
\end{tabular}

Surprisingly big number of bacteria has been seen in the water after ion-exchange deposits. However, the lack of turbidity and a satisfactory physicochemical parameters of water showed that the cause of technological problems is not the presence of microorganisms. This was completely clear with a big number of bacteria and small organic carbon content and lack of changes in oxygen concentration in the test water samples (Tab. 3).

The results of the analyses of $\mathrm{X}$-ray spectroscopy confirmed the presence of trace amounts of heavy metals: $\mathrm{Ti}, \mathrm{Cr}, \mathrm{Mn}, \mathrm{Fe}, \mathrm{Ni}, \mathrm{Cu}, \mathrm{Zn}, \mathrm{Pb}$ and potassium, silicon, sulphur and chlorides. Documentation and analysis of characteristics of chemical reagents used cards as flushing solutions, points to such a possibility, since one of the substances included in the flushing solution is potassium silicate (ARDROX).

Silicates present in water (Fig.2) attest to the fact that treatment is designed to remove all ions with the exception of silica. The literature indicates that in water solution alkali silicates, for example potassium silicate or sodium, are hydrolysed and produce silicic acid The acid tends to drainage and condensation 
with the creation of polysilicon acids. The process of condensation is accompanied by the formation of more and larger molecules, which show a lower solubility in water, giving the colloidal solutions. Better condensates, evolve in the form of gelatinous sediment. The speed of the condensation process largely depends on the $\mathrm{pH}$ of the solution, it is the largest in cases where the $\mathrm{pH}$ is 6-7 and clearly decreases when the acidity increases or decreases. In aqueous solution strongly alkaline $\mathrm{pH}$ approx. 13 and in strongly acidic aqueous solution ( $\mathrm{pH} 2-3)$, the rate of condensation is very small and diluted a silicic acid is stable. In the natural waters the silicates may exist in the form of ortho-, meta, and in the form of polyacids. Dissolved in water, there are gems in dissociated form but lowering the $\mathrm{pH}$ below the 8.3 undoes dissociation which promotes the formation of polyacids and extract the silica in solid form [1]. Polymerized silicates occur in colloidal form, so it is observed an increase in turbidity and reduce the silicate dissociated content (Fig.2). Other parameters fluctuate slight extent and during the process there is no clear trend of their changes (Tab. 4.).

The most effective and efficient method of removing silicates from technological water is ion-exchange method. Silicic acid anion $\mathrm{SiO}_{3}{ }^{2-}$ is removed by strongly alkaline anion exchange resin in the demineralization of water carried out in the system: strongly acidic cation exchanger in hydrogen form and strongly alkaline anion ion-exchanger in hydroxyl form [4]. It is also possible desilicanization of water using weak alkaline anion ion-exchanger. Then, before the hydrogen cation exchanger the $\mathrm{NaF}$ should be dosed to water. On cation exchanger there is the following reaction:

$$
\mathrm{NaF}+\mathrm{KtH} \leftrightarrow \mathrm{KtNa}+\mathrm{HF} \text {, Kt- strongly acidic cation exchanger. }
$$

$\mathrm{HF}$ formed reacts with the silica $\mathrm{SiO}_{2}$ and forms hexafluorosilicic acid:

$$
6 \mathrm{HF}+\mathrm{SiO}_{2} \rightarrow \mathrm{H}_{2} \mathrm{SiF}_{6}+2 \mathrm{H}_{2} \mathrm{O}
$$

Fluorosilicone acid anion is removed from the water during of the ion-exchange process on according to the reaction:

$\mathrm{H}_{2} \mathrm{SiF}_{6}+\mathrm{An}(\mathrm{OH})_{2} \leftrightarrow \mathrm{AnSiF}_{6}+2 \mathrm{H}_{2} \mathrm{O}, \mathrm{An}$ - weak alkaline anion exchanger.

With analysis of the documentation shows that water demineralization system is based on filtration through a strongly acidic cation exchanger and weakly alkaline anion exchanger without $\mathrm{NaF}$ dosing.

It seems necessary to supplement the system of additional filter of strongly basic anion exchange resin. Mechanical cleaning combined with disinfection of demineralization station causes temporary improvement, however, the issue of deterioration of water quality persists. 


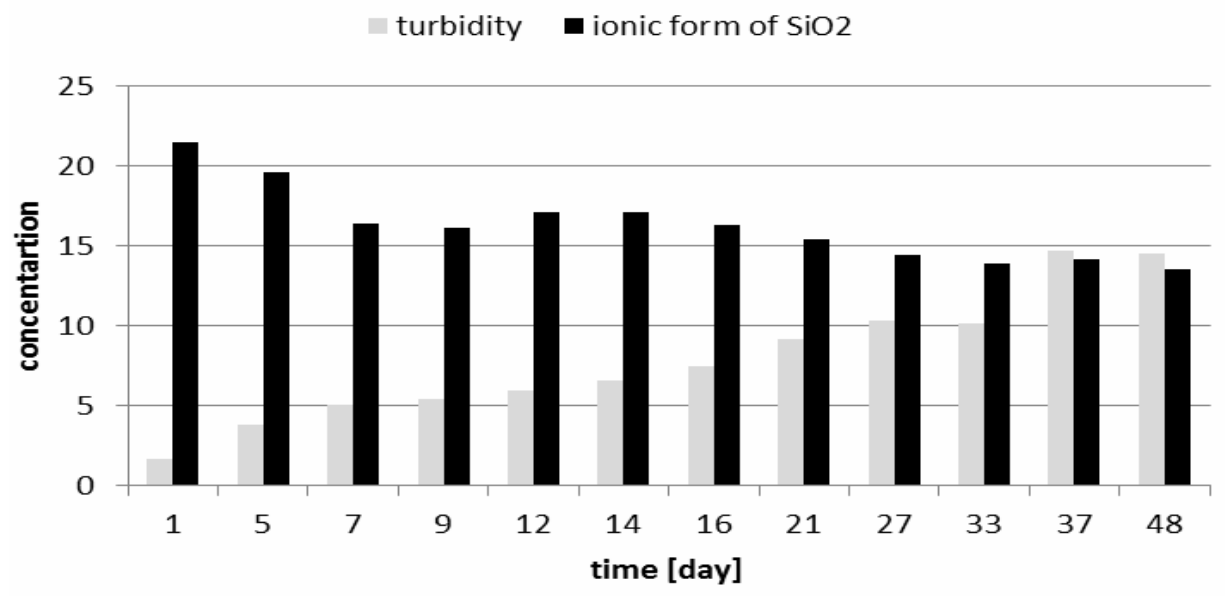

Fig. 2. Change the parameters of rinse water

Rys. 2. Zmiany parametrów wody płuczącej

Table 4. Changes in the quality of rinse water during installation work

Tabela 4. Zmiany jakości wody płuczącej w czasie pracy instalacji

\begin{tabular}{|c|c|c|c|c|c|c|c|}
\hline Day & $\mathrm{pH}$ & $\begin{array}{c}\text { Conduct.; } \\
\mu \mathrm{S} / \mathrm{cm}\end{array}$ & $\begin{array}{c}\text { Turbidity; } \\
\mathrm{NTU}\end{array}$ & $\begin{array}{c}\text { Total hardn.; } \\
\mathrm{mg} \mathrm{CaCO}_{3} / 1\end{array}$ & $\begin{array}{c}\text { Permang. } \\
\text { index; } \mathrm{mgO}_{2} / 1\end{array}$ & $\begin{array}{c}\mathrm{DO} ; \\
\mathrm{mgO}_{2} / 1\end{array}$ & $\begin{array}{c}\mathrm{SiO}_{3}{ }^{2-} ; \\
\mathrm{mgSiO}_{2} / 1\end{array}$ \\
\hline 1 & 8,01 & 4,57 & 1,62 & 0 & 1,3 & 8,44 & 21,5 \\
\hline 7 & 8,65 & 14,82 & 3,77 & 0 & 3,1 & 8,7 & 19,58 \\
\hline 9 & 8,38 & 5,65 & 5,02 & 0 & 2,3 & 9,55 & 16,4 \\
\hline 11 & 7,75 & 8,16 & 5,39 & 0 & 1,7 & 8,59 & 17,1 \\
\hline 14 & 7,27 & 20,17 & 5,98 & 0 & 1,8 & 8,58 & 17,06 \\
\hline 16 & 7,51 & 9,44 & 6,59 & 0 & 2,4 & 8,23 & 17,09 \\
\hline 18 & 7,37 & 6,19 & 7,47 & 0 & 2,1 & 8,37 & 16,26 \\
\hline 23 & 7,19 & 8,07 & 9,11 & 0 & 2,5 & 8,65 & 15,44 \\
\hline 28 & 9,13 & 9,55 & 10,3 & 0 & 2,8 & 9,03 & 14,45 \\
\hline 34 & 7,7 & 4,41 & 10,1 & 0 & 1,9 & 8,74 & 13,84 \\
\hline 38 & 7,75 & 2,66 & 14,7 & 0 & 2,4 & 8,47 & 14,11 \\
\hline 50 & 7,6 & 4,32 & 14,5 & 0 & 2,9 & 8,91 & 13,55 \\
\hline
\end{tabular}

\section{Conclusions}

1. The cause of the deterioration of the quality of the rinsing water and the formation of deposits on the elements is its technology of cleaning.

2. The results of the analyses indicate that the cause of the growth of technological water turbidity on the FPI is formation of polysilicon acid.

3. Polymerized forms of silicates exist in colloidal form, therefore, the observed phenomenon is the emergence of so-called "white water" and the formation of deposits. 
4. Improvement of technological water quality can be achieved by:

- carrying out a thorough cleaning of rinsing system and removal of accumulated sediments,

- maintaining the technological regime on individual stages of the process of rinsing,

- the insertion additional, strongly alkaline anion exchanger working in hydroxyl circle, in order to continuously removing silicates from the water.

\title{
Bibliography
}

[1] Bielański A. General and Inorganic Chemistry. PWN Warsaw 2013 ((in polish).

[2] Flemming H. Microbial growth on ion exchangers, Water Research, Vol. 21, Issue 7, p. 745-756, 1987.

[3] Puszkarewicz A., Kaleta J. Water treatment for special purposes. Publishing House of Technical University of Rzeszów, 2013 (in polish).

[4] http://ce4mro.com/index.php/news [access: 9 April 2015 r ].

[5] http://www.cnde.iastate.edu/etc/engineerin\%20study\%20fluorescent $\% 20$ penetrant.pdf [access: 9 April 2015].

[6] http://www.ndt.net/article/ecndt98/aero/031/031.htm [access: 3 April 2015].

[7] http://www.ndt24.pl/pl/dokumenty/systemy_fpi [access: 3 April 2015].

[8] http://www.radus.pl/pdf/biuletyny/OCZYSZCZANIE_1.pdf [access: 9 April 2015].

\section{UZDATNIANIE WODY TECHNOLOGICZNEJ DLA POTRZEB PRZEMYSŁU LOTNICZEGO - PROBLEMY EKSPLOATACYJNE}

\begin{abstract}
Streszczenie
W artykule przedstawiono technologię uzdatniania wody dla potrzeb linii FPI (fluorescencji i czyszczenia chemicznego) do prowadzenia badań diagnostycznych elementów konstrukcyjnych w zakresie pęknięć, erozji, korozji, ubytków materiału, spójności spawów. W omawianym przykładzie linia fluorescencji i czyszczenia chemicznego składa się ze stacji demineralizacji wody oraz z wanien, w których odbywa się proces płukania produkowanych elementów. Problemem, który pojawił się podczas eksploatacji linii FPI był wzrost mętności i mlecznej barwy wody (tzw. białej wody) w wannie z ostatniego płukania co powodowało powstawanie osadów na płukanych elementach i utrudniało proces diagnostyczny. Na podstawie analiz fizyko-chemicznych i bakteriologicznych dokonano oceny zmian jakości wody podczas procesu czyszczenia. Opisano i rozwiązano problem związany z powstawaniem tzw. „,białej wody”. Dokonano analizy konieczności modernizacji stacji uzdatniania oraz zasadności zastosowania procesu dezynfekcji. Analizowano następujące parametry wody: $\mathrm{pH}$, mętność, przewodnictwo, twardość, tlen rozpuszczony, ogólny węgiel organiczny, indeks nadmanganianowy, zawartość $\mathrm{SiO}_{2}$, metali ciężkich oraz ogólną liczbę bakterii mezofilnych i psychrofilnych.
\end{abstract}

Słowa kluczowe: krzemionka koloidalna, uzdatnianie wody, linia fluorescencji i czyszczenia chemicznego FPI

Przestano do redakcji: 30.05.2015 $r$.

Przyjęto do druku: 30.10 .2015 r.

DOI: $10.7862 / \mathrm{rb} .2015 .117$ 